\title{
Preferential Uptake of Restriction Fragments from a Gonococcal Cryptic Plasmid by Competent Neisseria gonorrhoeae
}

\author{
By KERRY L. BURNSTEIN,${ }^{1 *} \dagger$ DAVID W. DYER ${ }^{2}$ AND \\ P. FREDERICK SPARLING ${ }^{1,2}$ \\ Curriculum in Genetics ${ }^{1}$ and Department of Microbiology and Immunology ${ }^{2}$, School of Medicine, \\ University of North Carolina at Chapel Hill, Chapel Hill, NC 27514, USA
}

(Received 14 July 1987)

\begin{abstract}
Factors involved in the specificity of DNA uptake by competent Neisseria gonorrhoeae were examined. Host-controlled modification did not affect uptake. Certain restriction fragments of the $4.2 \mathrm{~kb}$ gonococcal cryptic plasmid pFAl and of the replicative form of the bacteriophage M13 were taken up in preference to others, independent of differences in fragment size. A 600 bp fragment from the $4.2 \mathrm{~kb}$ plasmid was cloned into pLES2, a gonococcal-Escherichia coli shuttle vector; the $600 \mathrm{bp}$ fragment was taken up into a DNAase-I-resistant state in preference to the vector fragment. A second $370 \mathrm{bp}$ fragment in pFA1 was also taken up preferentially. The $600 \mathrm{bp}$ and $370 \mathrm{bp}$ fragments share a $10 \mathrm{bp}$ sequence, which is found in pFAl only on fragments that were taken up readily. However, a fragment from M13 which was efficiently taken up did not contain this $10 \mathrm{bp}$ sequence. In addition, this sequence was not sufficient to direct preferential DNA uptake by gonococci, since a recombinant plasmid containing this $10 \mathrm{bp}$ sequence was not taken up appreciably better than the vector plasmid or another recombinant plasmid containing an unrelated 10 bp sequence. Sequence comparisons of the three restriction fragments which were preferentially taken up did not yield any consensus sequences greater than $7 \mathrm{bp}$. Although it is likely that efficient uptake of DNA by gonococci is determined by DNA structure, a single short sequence could not be found that accounted for specific uptake.
\end{abstract}

\section{INTRODUCTION}

Neisseria gonorrhoeae is unusual among bacterial species in that nearly all isolates constitutively express competence for genetic transformation (Biswas et al., 1977; Sparling, 1966). The gonococcus is also unusual in the apparent specificity for recognition of homologous DNA during the early stages of DNA uptake by competent cells (Dougherty et al., 1979); in this respect this organism resembles competent Haemophilus influenzae, which also exhibits preferential uptake of homologous DNA (Scocca et al., 1974). In most other transformable bacteria, no specificity is exhibited during DNA uptake (Smith et al., 1981).

The mechanism for specific uptake of homologous DNA by $H$. influenzae has been studied extensively (Goodgal, 1982; Smith et al., 1981), and there is evidence that DNA uptake is facilitated by the presence of a specific 11 bp sequence (Danner et al., 1980; Deich \& Smith, 1980). The basis for specific uptake of gonococcal transforming DNA is much less well understood. Dougherty et al. (1979) found that a 100-fold excess of heterologous DNA did not inhibit transformation by gonococcal DNA to streptomycin resistance. Homologous and heterologous DNAs were bound by piliated competent gonococci, but only homologous DNA was taken up into a DNAase-I-resistant form (Dougherty et al., 1979). Similarly, Graves et al. (1982a) showed that Escherichia coli DNA was unable to competitively inhibit transformation of gonococcal chromosomal DNA, or a gonococcal $\beta$-lactamase-encoding ( $\left.\mathrm{Pc}^{r}\right)$ plasmid, pFA10. Graves et al. (1982b) also demonstrated that gonococci selectively internalized specific

† Present address: Department of Physiology, University of North Carolina at Chapel Hill. 
fragments from restriction digests of pFA10. pFA10 is an $11.5 \mathrm{~kb}$ hybrid plasmid composed of the $7.2 \mathrm{~kb} \mathrm{Pc}$ plasmid (pFA3) and the $4.2 \mathrm{~kb}$ gonococcal cryptic plasmid (pFA1) (Graves et al., $1982 \mathrm{~b}$ ). Gonococci preferentially took up a $1.5 \mathrm{~kb}$ TaqI and a $3.0 \mathrm{~kb} \mathrm{MspI}$ fragment from pFA10 (Graves et al., 1982b). These fragments consist of pFA1 sequences and overlap by $600 \mathrm{bp}$. Graves et al. (1982b) speculated that the pFAl portion of pFA10 was preferred for uptake because it consisted of homologous gonococcal DNA. However, since end-labelled pFA10 restriction fragments were used as donor DNA in uptake, it was possible that additional fragments were taken up also, but not detected due to removal of the terminal ${ }^{32} \mathrm{P}$ label.

This paper reports the results of experiments designed to examine the question of preferential uptake of specific restriction fragments by gonococci, and to determine the structural basis for preferential uptake.

\section{METHODS}

Bacterial strains and plasmids. These are described in Table 1.

Media. Gonococci were cultured on Difco GC base agar medium plus supplements as previously described (Sarubbi et al., 1974). E. coli strains were grown in LB medium or on LB agar (Maniatis et al., 1982); ampicillin was added at $50 \mu \mathrm{g} \mathrm{ml}^{-1}$ as indicated. For analysis of DNA uptake and genetic transformation of gonococci, GCB broth plus $10 \mathrm{mM}-\mathrm{MgCl}_{2}$ was used, as described by Biswas et al. (1986a).

DNA purification. Plasmid DNA was isolated from gonococci as described by LeBlanc \& Hassel (1976), and from E. coli by the alkaline lysis method of Birnboim \& Doly (1979) as modified by Maniatis et al. (1982); the DNAs were then further purified by one or two cycles of $\mathrm{CsCl} /$ ethidium bromide density-gradient centrifugation (Radloff et al., 1967).

Restriction endonuclease digestions. These were done according to the instructions supplied by the manufacturers (Bethesda Research Laboratories, New England Biolabs and International Biotechnologies).

Transformation. N. gonorrhoeae was transformed as described by Sox et al. (1979). E. coli was transformed by the calcium chloride procedure of Dagert \& Ehrlich (1979) or by the method of Hanahan (1983).

Labelling of plasmid DNA. pFA10 was nick-translated using $\left[\alpha^{32} \mathrm{P}\right] \mathrm{dCTP}$ (ICN Pharmaceuticals or New England Nuclear) and reagents from Bethesda Research Laboratories; reaction conditions were as recommended by the supplier. pFA1 restriction fragments were labelled by the replacement synthesis method of O'Farrell et al. (1980). Unincorporated $\left[\alpha^{-32}\right.$ P]dCTP was removed by gel filtration on a $5 \mathrm{ml}$ Sephadex G-100 (Pharmacia) column. Specific activities of the DNA ranged from $10^{6}$ to $10^{7}$ c.p.m. $\mu \mathrm{g}^{-1}$. Oligonucleotides were end-labelled as described by Maniatis et al. (1982). Unincorporated [ $\gamma^{-32}$ P]ATP was removed by ethanol precipitation.

Restriction fragment uptake assay. Radioactively-labelled restriction fragments that entered into a DNAase-Iresistant state were detected by autoradiography by the method of Graves et al. (1982b). Alternatively, unlabelled fragments were used for uptake and detected by hybridization. In both assays, 1-2 $\mu \mathrm{g}$ of plasmid restriction fragments were incubated with $1 \mathrm{ml}$ of piliated FA759 gonococci (approximately $5 \times 10^{7}$ c.f.u.) in GCB broth

\section{Table 1. Bacterial strains and plasmids}
Strain
Plasmid content
Description (reference)

N. gonorrhoeae

FA759

FA6058

FA675

$\begin{array}{ll}\begin{array}{l}\text { E. coli } \\ \text { JM83 }\end{array} & \text { None } \\ \text { DH5 } & \text { None }\end{array}$

FA6269

FA6270

FA6239

None

None
No autonomous plasmid

pFA1, 4.2 kb gonococcal cryptic plasmid

pFA10, 11.5 kb hybrid of pFA1 and pFA3, a $\beta$-lactamase-encoding plasmid

pLES2, $6.0 \mathrm{~kb}$ gonococcal-E. coli shuttle vector

pSTD6, 6.6 kb recombinant of pLES2 and $600 \mathrm{bp} \mathrm{HpaII-TaqI}$ fragment from $4.2 \mathrm{~kb}$ gonococcal cryptic plasmid, pJD1 pFA10
Clinical isolate (Graves et al., 1982b)

Construction from FA759 (Biswas et al., 1986b)

$\mathrm{Pc}^{\mathrm{r}}$ (pFA10) (Graves et al., 1982a,b) transformant of FA759 (Graves et al., 1982b)

K12 strain (ara $\Delta$ lac-pro strA thi $\phi 80 \mathrm{~d}$ lacZ $\Delta \mathrm{M} 15$ ) (Vieira \& Messing, 1982) $\mathrm{F}^{-}$endA1 hsdR17 $\left(\mathrm{r}_{\mathrm{k}}^{-}, \mathrm{m}_{\mathrm{k}}^{+}\right)$supE44 thi-1 $\lambda^{-}$ recAl gyrA96 relA1 $\phi 80 \mathrm{~d} l a c Z \Delta \mathrm{M} 15$ (Bethesda Research Laboratories)

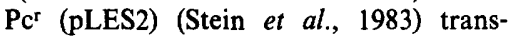
formant of JM83

Construction; $\mathrm{Pc}^{\mathrm{r}}$ (pSTD6) transformant of JM83

$\operatorname{Pc}^{r}$ (pFA10) (Graves et al., 1982a,b) transformant of JM83 
containing $10 \mathrm{mM}-\mathrm{MgCl}_{2}$. In some experiments, nonpiliated gonococci were treated in parallel as a control. After $10 \mathrm{~min}$ at $37^{\circ} \mathrm{C}$, DNAase I was added to $160 \mu \mathrm{g} \mathrm{ml}^{-1}$ and the cells were held on ice for $20 \mathrm{~min}$. The cells were then washed three times by centrifugation in ice-cold A medium (Davis minimal medium, Difco) containing $0.25 \mathrm{M}-$ $\mathrm{NaCl}$. The final cell pellets were resuspended in lysis buffer $(50 \mathrm{~mm}$-glucose, $25 \mathrm{~mm}$-Tris/HCl, $\mathrm{pH} 8.0,10 \mathrm{mM}-$ $\mathrm{Na}_{2}$ EDTA) and sodium dodecyl sulphate (SDS) was added to $1 \%(\mathrm{w} / \mathrm{v})$. This mixture was incubated at $65^{\circ} \mathrm{C}$ for $10 \mathrm{~min}$, which was sufficient to lyse the cells. Samples were deproteinized by successive extractions in $\mathrm{CHCl}_{3} /$ phenol and $\mathrm{CHCl}_{3}$; the nucleic acids were precipitated with ammonium acetate and ethanol. The nucleic acid precipitate was dissolved in TE buffer $\left(10 \mathrm{~mm}-\mathrm{Tris} / \mathrm{HCl}, \mathrm{pH} 8 \cdot 0\right.$, and $\left.1 \mathrm{~mm}-\mathrm{Na}_{2} \mathrm{EDTA}\right)$ for electrophoresis.

Agarose gel electrophoresis, hybridization and autoradiography. Electrophoresis of plasmid DNA was performed on horizontal agarose gels in Tris/acetate/EDTA buffer (Maniatis et al., 1982). DNA recovered from gonococcal cell lysates was electrophoresed on $1-1.2 \%(\mathrm{w} / \mathrm{v})$ gels and compared to ${ }^{32} \mathrm{P}$-labelled standards. To detect uptake of labelled restriction fragments, the gels were fixed at room temperature in $10 \%(\mathrm{v} / \mathrm{v})$ methanol and $10 \%(\mathrm{v} / \mathrm{v})$ acetic acid with agitation for $10 \mathrm{~min}$ and blotted dry. Kodak X-AR5 film was exposed to the dried gels for 3-7 d with a Cronex Lightning-Plus intensifier screen at $-70^{\circ} \mathrm{C}$. When hybridization was used to detect uptake of plasmid restriction fragments, DNA samples were transferred from agarose gels to nitrocellulose filter paper (BA85, Schleicher and SchuelI) by the procedure of Smith \& Summers (1980). Filters were probed and washed by standard procedures (Maniatis et al., 1982). Autoradiography was performed as described above.

Uptake assays of intact pFA10. pFA10, used in uptake experiments, was isolated from E. coli FA6239 or N. gonorrhoeae $\mathrm{FA675}$ and twice purified by $\mathrm{CsCl}$ /ethidium bromide density-gradient centrifugation. The hybridization uptake assay was done as previously described (Biswas et al., 1986a).

Construction of recombinant plasmid pSTD6. Plasmid pGUT was kindly supplied by Dr M. So; it contains an approximately $600 \mathrm{bp}$ insert of the HpaII-TaqI fragment (on EcoRI linkers) from pJD1, a gonococcal $4.2 \mathrm{~kb}$ cryptic plasmid (Davies \& Normark, 1980; Korch et al., 1985). pGUT was digested with EcoRI and the 600 bp cryptic plasmid fragment was purified by electroelution (Maniatis et al., 1982). This fragment was ligated with EcoRI-cleaved pLES2, a gonococcal-E. coli shuttle vector (Stein et al., 1983) and used to transform $E$. coli JM83.

Cloning and DNA sequencing. The $370 \mathrm{bp}$ DdeI pFAl fragment was electroeluted and the single-stranded ends were filled in using T4 DNA polymerase and all four deoxyribonucleotide triphosphates, as described by Maniatis et al. (1982). EcoRI linkers (Bethesda Research Laboratories) were phosphorylated using ATP and T4 polynucleotide kinase (Bethesda Research Laboratories) and were ligated to the blunt-ended DdeI fragment using T4 DNA ligase as recommended by the supplier. The recombinant DNA was digested with 30 units of EcoRI, added in two aliquots, and then electrophoresed on a $5 \%(\mathrm{w} / \mathrm{v})$ polyacrylamide gel; the $370 \mathrm{bp}$ band was excised and eluted (Maniatis et al., 1982). EcoRI-cleaved replicative form M13 (mp19) was ligated to the $370 \mathrm{bp}$ fragment and used to transform JM109. Phage DNA from some of the colourless plaques was purified from $1.5 \mathrm{ml}$ cultures and sequenced by the chain-termination method (Sanger et al., 1977). DNA sequences were compared using Pustell's Sequence Analysis programs (International Biotechnologies).

Synthesis and purification of oligonucleotides. The following oligonucleotides (obtained from Dr C. A. Hutchison) were synthesized, excised and purified as described by Hutchison et al. (1986).

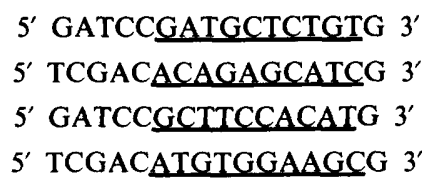

The complementary oligonucleotides ( 1 and $2 ; 3$ and 4) were annealed as described by Hutchison et al. (1986) to generate double-stranded oligonucleotide pairs that contain a $S a I$ and a BamHI cohesive end (sequences that make up the $S a l I$ and $B a m H I$ ends are not underlined). To confirm the accuracy of the chemical synthesis, oligonucleotide-containing clones were sequenced by the chain-termination method (Sanger et al., 1977).

Construction of pBR322 derivatives. The $4 \mathrm{~kb}$ fragment from a BamHI, SalI pBR322 digest was electroeluted as described by Maniatis et al. (1982) and ligated to the annealed oligonucleotides, as desribed by Hutchison et al. (1986). A $1-3 \mu$ l volume of a $1: 5$ dilution in TE buffer of the ligation mix was used to transform competent DH5 $\alpha$ (Bethesda Research Laboratories). pBR322 derivatives containing oligonucleotides were identified from several ampicillin-resistant, tetracycline-sensitive transformants by hybridization of plasmids from mini-preparations to the ${ }^{32} \mathrm{P}$-end-labelled homologous oligonucleotide. Hybridizations were performed at room temperature in $6 \times$ SSC, $10 \%$ Denhardt's solution (Maniatis et al., 1982), $100 \mu \mathrm{g} \mathrm{m}^{-1}$ each of yeast RNA and denatured salmon sperm DNA and $0 \cdot 1 \%$ SDS. Washes were in $6 \times \mathrm{SSC}$ at room temperature. The $4 \mathrm{~kb} \mathrm{BamHI}-S a l \mathrm{l}$ pBR 322 fragment was end-repaired and blunt-end ligated (Maniatis et al., 1982) to generate the 265 bp deletion derivative pBR322 $\triangle B-S$.

Scanning densitometry. An LKB model 2202 Ultroscan densitometer was used to compare intensities of bands appearing on the same autoradiographs. Bands were scanned twice at approximately one-third and two-thirds width of each band. 


\section{RESULTS}

\section{pFA10 restriction fragments are not processed during uptake}

To determine whether the observations of Graves et al. (1982b) could be explained by processing of DNA fragments rather than by preferential uptake, we used a hybridization assay to detect internalized DNA which had become DNAase I resistant. When an MspI digest of pFA10 was used as donor DNA, the $3.0 \mathrm{~kb} \mathrm{MspI} \mathrm{fragment} \mathrm{was} \mathrm{preferentially} \mathrm{taken} \mathrm{up} \mathrm{(data} \mathrm{not}$ shown) as determined by its ability to hybridize with nick-translated pFA10. The other restriction fragments from the digest were not taken up. These data indicated that the $3.0 \mathrm{~kb}$ MspI fragment was taken up preferentially by gonococci from a mixture of pFA10 MspI restriction fragments, as suggested by Graves et al. $(1982 b)$. Furthermore, restriction fragments did not appear to undergo extensive processing during or immediately following uptake into a DNAase-I-resistant state.

\section{The TaqI-MspI fragment from the cryptic plasmid is recognized for uptake}

The $3.0 \mathrm{~kb} \mathrm{MspI}$ and $1.5 \mathrm{~kb}$ TaqI pFA10 fragments, which are taken up preferentially as described by Graves et al. (1982b), overlap by approximately $600 \mathrm{bp}$. Both of these fragments lie within the pFAl portion of pFA10 (Graves et al., 1982b). We tested whether this common 600 bp region was specifically recognized for uptake. For this experiment we used the equivalent fragment from another cryptic plasmid isolate, pJD1, since this particular plasmid had been sequenced (Korch et al., 1985). pFA1 and pJD1 are similar, based on restriction enzyme digest patterns (Davies \& Normark, 1980; Foster \& Foster, 1976; Korch et al., 1985; and unpublished

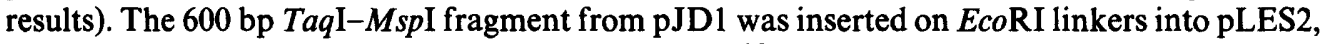
resulting in pSTD6. An EcoRI digest of pSTD6 was ${ }^{32} \mathrm{P}$-labelled by the replacement synthesis method and exposed to competent gonococci. The $600 \mathrm{bp}$ fragment was taken up in preference to the vector fragment (Fig. 1).

\section{Identification of a second region on the cryptic plasmid which is preferentially taken up}

Since fragments taken up from pFA10 were found exclusively on the pFA1 portion of pFA10, we utilized pFA1 to extend the findings of Graves et al. (1982b). We first wished to see if the $1.5 \mathrm{~kb}$ TaqI fragment would be taken up preferentially from pFA1, as it is from pFA10 (Graves et al., 1982 b). We confirmed that the $1.5 \mathrm{~kb}$ fragment was selectively taken up, but in addition a smaller fragment of approx. $400 \mathrm{bp}$ was taken up to a lesser extent (data not shown). Since there are three pFAl TaqI restriction fragments of about $400 \mathrm{bp}$, we were unable to tell which small TaqI fragment was taken up. We therefore examined uptake of other restriction digests of pFA1 to locate the plasmid location of this second fragment.

Two fragments were taken up from a pFA1 DdeI digest (Fig. 2, lanes A and B). The largest of the two DdeI fragments (approx. $3 \mathrm{~kb}$ ) contains the $600 \mathrm{bp}$ TaqI-MspI fragment, but in addition a smaller $370 \mathrm{bp} D d e I$ fragment was taken up. Three other DdeI fragments were not taken up appreciably. The second, smaller DdeI fragment apparently was not taken up to the same extent as the larger fragment (Fig. 2, lane B). Two of four fragments from an NciI, SspI and AvaII triple digest of pFA1 also were preferentially taken up (Fig. 2, lanes $\mathrm{C}$ and D). In this experiment, the two fragments from the triple digest which were taken up (Fig 2, lane D) migrated more slowly than the purified fragments (Fig. 2, lane C) used as standards. This occurred occasionally and may have been due to differences in the preparation of the fragments used as standards ( $\mathrm{CsCl} /$ ethidium bromide density gradients) as compared to the DNA recovered following uptake (crude gonococcal SDS lysates). Each of these two fragments from the triple digest overlap the two DdeI fragments that are recognized for uptake preferentially. HinfI cuts pFAl twice and both of the resulting fragments were taken up (Fig. 2, lanes $E$ and F). The larger HinfI

Fig. 2. Preferential uptake of two regions of the cryptic plasmid pFAl. Lanes A, C, E, ${ }^{32}$ Preplacement-synthesis-labelled pFAl DdeI fragments (lane A), fragments from an NciI, AvaII and SspI pFA1 triple digest (lane C), and fragments from a HinfI pFAl digest (lane E). Lanes B, D, F, DNA recovered from gonococci exposed to ${ }^{32} \mathrm{P}$-labelled DdeI fragments (lane B), NciI, AvaII and SspI fragments (lane D) and HinfI fragments (lane F). 
A

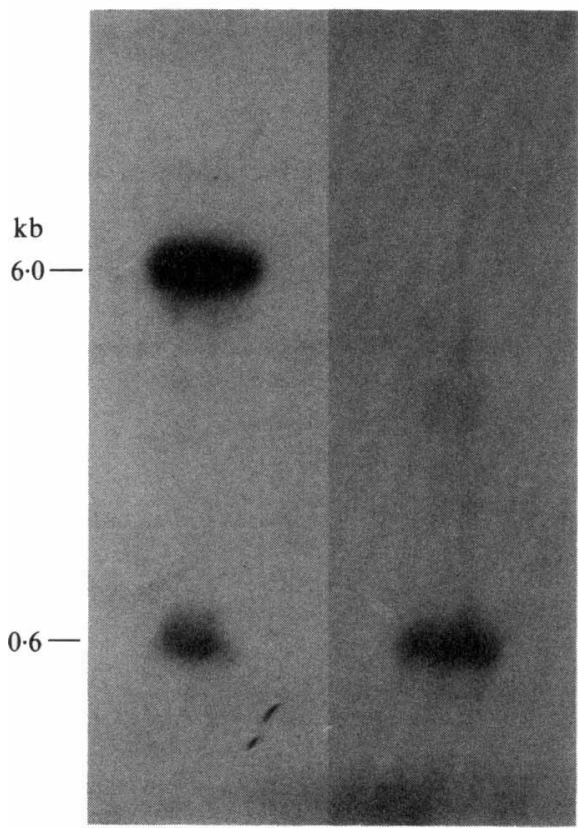

Fig. 1. Uptake of the $600 \mathrm{bp}$ TaqI-MspI cryptic plasmid fragment in preference to the $6 \mathrm{~kb}$ vector pLES2. Lane A, EcoRI-digested pSTD6 ${ }^{32}$ P-labelled by replacement synthesis. Lane B, DNA recovered from gonococci which were incubated with radiolabelled pSTD6 EcoRI fragments.

A

B

$\mathrm{kb}$

$2 \cdot 71$

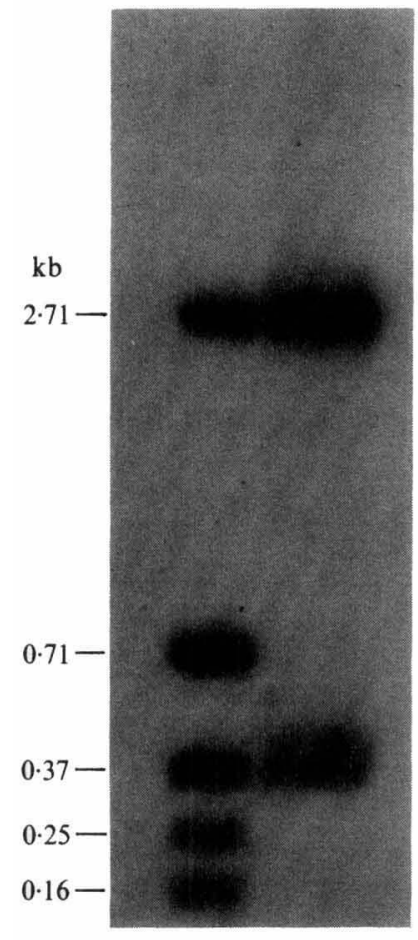

C

D

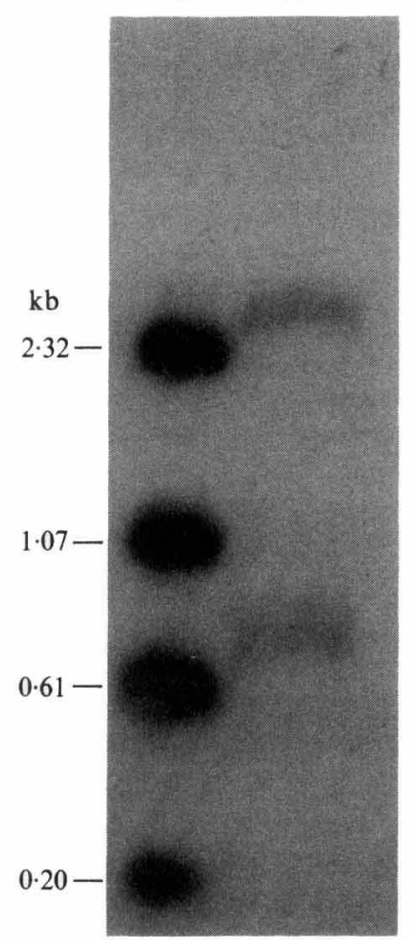

E F

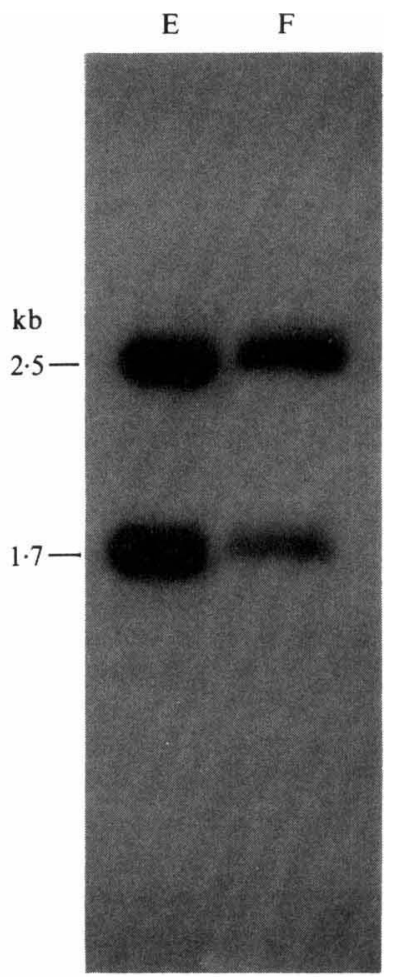




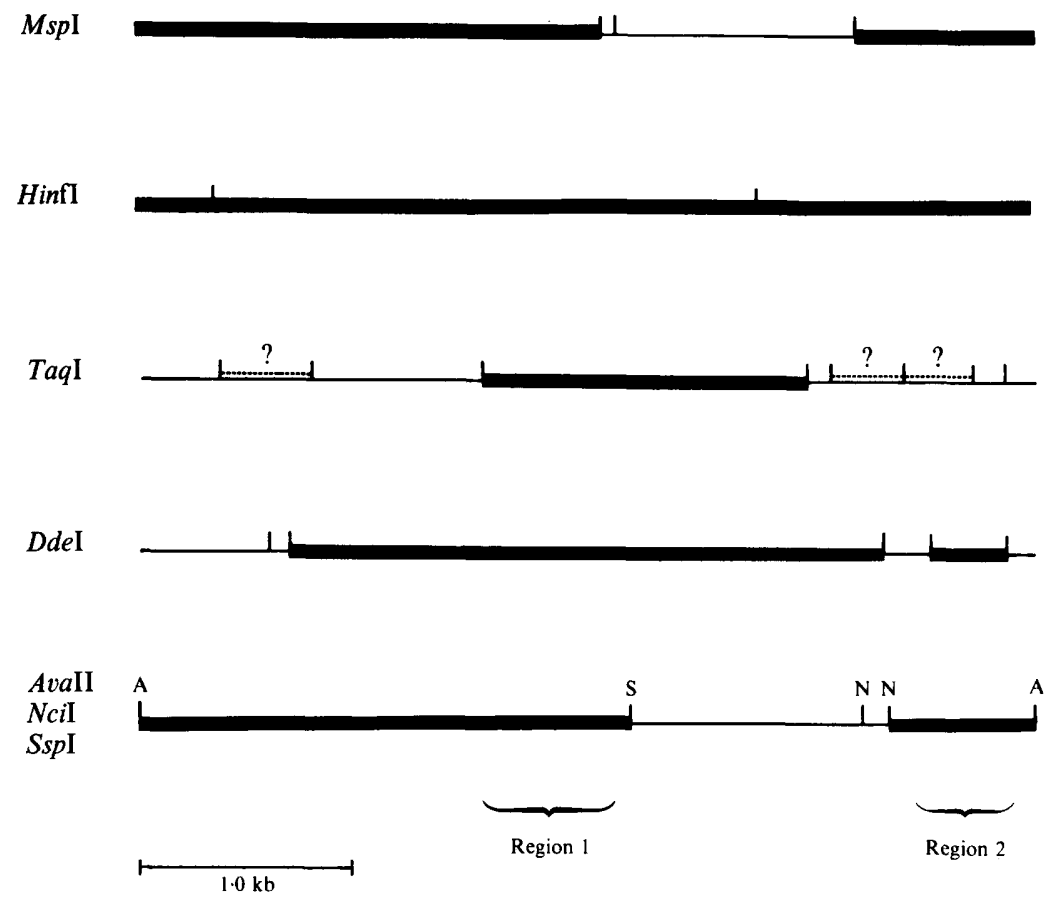

Fig. 3. Restriction maps of pFA1; fragments taken up preferentially by competent gonococci are shown as bold lines. Regions 1 and 2 denote portions common to all pFA1 fragments taken up. Region 1 is also referred to as the $600 \mathrm{bp} T a q \mathrm{I}-M s p \mathrm{I}$ overlap. It was unclear which of the similarly sized TaqI fragments (labelled with question marks) were taken up.

600 bp TaqI-MspI fragment (1590-2190)

$5 '$......AataAaccGC GATGCTCtgt ACtcGgCATt..... 3'

370 bp DdeI fragment (3711-4080)

\section{$5^{\prime}$......AGCCGTCTGT GATGCTCTGT GATGCTCTGT GCGGCTTCCT.... $3^{\prime}$}

Fig. 4. A 10 bp sequence is common to the two cryptic plasmid fragments taken up. The underlined sequence is the $10^{*}$ mer as it is found on the cryptic plasmid pJD1 (Korch et al., 1985). Numbers in parentheses represent the map sites of the TaqI-MspI and DdeI fragments from the AvaII site on pJD1.

fragment contains the $600 \mathrm{bp} M s p I-T a q I$ overlap fragment and appears darker than the smaller HinfI fragment, which encompasses the $370 \mathrm{bp} D d e I$ fragment. This suggests that the $600 \mathrm{bp}$ region (designated region 1) was taken up more efficiently than the 360 bp DdeI fragment (region 2). These results demonstrated that there were two distinct regions present on the gonococcal cryptic plasmid which were recognized for uptake; these data are summarized in Fig. 3.

We compared sequences of the $600 \mathrm{bp} T a q \mathrm{I}-\mathrm{MspI}$ overlap fragment in pJD1 and the $370 \mathrm{bp}$ DdeI pJD1 fragment (Korch et al., 1985); these fragments have a 10 bp sequence $\left(5^{\prime}\right.$ GATGCTCTGT $3^{\prime}$ ) in common which is not found elsewhere on pJD1 (Fig. 4). This sequence (denoted $10^{*}$ mer) is directly repeated in tandem in the $370 \mathrm{bp} D d e \mathrm{I}$ fragment. We sequenced the pFA1 370 bp DdeI fragment and found the repeated $10^{*}$ mer present on this fragment, exactly as in the published sequence for pJD1 (Korch et al., 1985). 


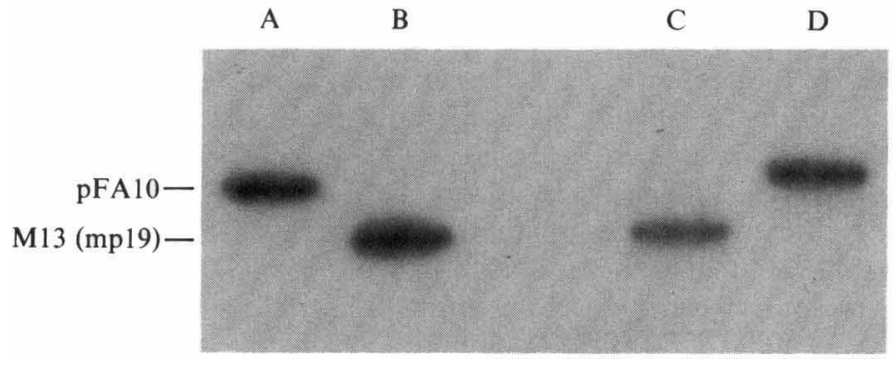

Fig. 5

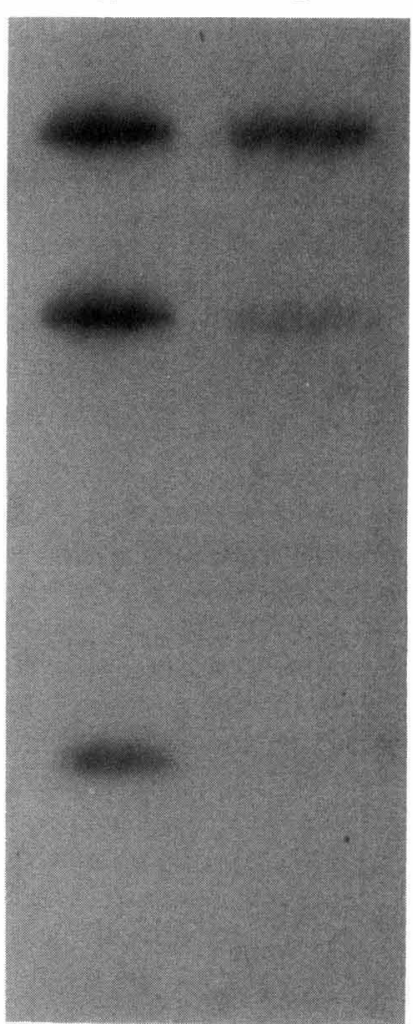

Fig. 6

Fig. 5. Uptake of radiolabelled M13 (mp19) DNA and pFA10 in the presence of competing unlabelled pFA10. Lanes A and B contain linearized pFA10 (HincII) and mp19 DNA (EcoRI), respectively. Both samples were radiolabelled by the replacement-synthesis procedure (see Methods). DNA recovered from gonococci incubated with $1 \mu \mathrm{g}$ each of unlabelled pFA10 and radiolabelled mp 19 (lane C) and pFA10 (lane D) is shown.

Fig. 6. Uptake of M13 (mp19) DNA restriction fragments. Lane A contains ${ }^{32}$ P-replacementsynthesis-labelled mp19 NciI fragments. Lane B contains DNA isolated from gonococci following exposure to mp19 NciI fragments.

\section{Bacteriophage M13 (mp19) replicative-form DNA competes with pFA10 for uptake}

Replicative-form DNA from the bacteriophage M13 was taken up well by gonococci (data not shown). To examine further the uptake of this heterologous DNA, we tested the ability of M13 (mp19) to compete for uptake with the hybrid plasmid pFA10. Linearized, radiolabelled M13 (mp19) DNA plus unlabelled intact pFA10 was incubated with gonococci. In a separate reaction, labelled pFA10 plus unlabelled pFA10 was also exposed to gonococci. The results indicated that M13 (mp19) DNA competed with pFA10 for uptake and was taken up almost as well (Fig. 5).

\section{A restriction fragment from $M 13$ (mp19) DNA is taken up preferentially}

We wanted to determine if certain regions of M13 DNA were taken up selectively as they were in pFAl. Radiolabelled $\mathrm{Ncil}$ restriction fragments of $\mathrm{M} 13$ (mp19) DNA were exposed to competent gonococci (Fig. 6). The largest $\mathrm{Ncil}$ fragment from the digest was taken up well but the second fragment was taken up only slightly and there was no detectable uptake of the smallest fragment. Similarly, the largest HaeIII fragment, which encompasses the NciI fragment, was preferentially taken up from a HaeIII digest of M13 DNA (data not shown). The 
sequence of the largest $\mathrm{NciI}$ fragment of M13 was compared to the sequences of the two regions of pJD1 (pFAl) which had been shown to be selectively taken up (see above). No consensus sequences greater than $7 \mathrm{bp}$ were found among the three fragments. Additionally, the M13 NciI fragment contained only a $6^{\prime}$ mer homologous to the $10^{*}$ mer identified on the two pFA1 fragments. The M13 genome does contain a perfect inner 8 bp sequence of the $10^{*}$ mer $\left(5^{\prime}\right.$ ATGCTCTG 3') but this sequence occurs outside the largest $\mathrm{NciI}$ fragment.

\section{The $10^{*}$ mer does not confer enhanced uptake on the pBR322 derivatives}

To determine if a pBR322 derivative containing the $10^{*}$ mer was specifically recognized for uptake by gonococci, we examined uptake of three pBR322 derivatives and pFA10 in the presence of competing, unlabelled pFA10. Two of the derivatives of pBR322 served as controls: one plasmid contained a 10 bp sequence $5^{\prime}$ GCTTCCACAT $3^{\prime}$ (unrelated to the $10^{*}$ mer) found once on the cryptic plasmid and in a region not taken up preferentially; the second plasmid contained no insert, but like the other two plasmids it lacked the BamHI-SalI 265 bp fragment of $\mathrm{pBR} 322$. Competing unlabelled $\mathrm{pFA} 10$ plus each of the radiolabelled $\mathrm{pBR} 322$ derivatives or pFA10 were incubated with piliated gonococci. pFA10 was added as a competitor in these experiments so that the $10^{*}$ mer would be rigorously tested for its ability to confer specific uptake on pBR322. We predicted that the $10^{*}$ mer would compete adequately with pFA10 if it were responsible for the preferential uptake of pFA1 (cryptic plasmid) sequences. All three pBR322 derivatives were poorly taken up (i.e. were not highly competitive with pFA10), whereas pFA10 was taken up at least 10 -fold better in the presence of equal amounts of competing unlabelled pFA10. The results of scanning densitometry of two autoradiographs from these experiments were as follows (mean peak values $\pm \mathrm{SD}$ from two or three readings): $\mathrm{pBR} 322 \Delta \mathrm{B}-\mathrm{S}, 260 \pm 125$; pBR322 $\Delta \mathrm{B}-\mathrm{S}+$ unrelated 10'mer, $160 \pm 100$; pBR322 $\Delta \mathrm{B}-\mathrm{S}+10^{*}$ mer, $308 \pm 43$; pFA10, $2929 \pm 54$. There were some subtle differences (rarely greater than twofold) in the uptake of the pBR322 derivatives; these probably resulted from variability in recovering DNA following uptake, since similar differences were also seen between identical duplicate samples. These results showed that the $10^{*}$ mer $5^{\prime}$ GATGCTCTGT $3^{\prime}$ was not sufficient to confer efficient uptake of pBR322.

\section{Gonococcal DNA modification is unnecessary for efficient uptake of pFA10}

Although there was selectivity in restriction-fragment uptake in the absence of any differences in DNA modification (Figs 1 and 2), we were curious whether homologous DNA modification was preferred over heterologous modification patterns. To test whether gonococcal DNA modification was required for efficient uptake, we examined the efficiency of uptake of pFA10 isolated from a gonococcal host (FA675) or E. coli (JM83). When pFA10 was isolated from $N$. gonorrhoeae FA675, it transformed FA759 (which is isogenic with FA675) at an efficiency of approximately $1 \times 10^{-4} \mathrm{Pc}^{\mathrm{r}}$ transformants per $\mu \mathrm{g}$ DNA. pFA10 isolated from $E$. coli JM83 transformed FA759 at about $2 \times 10^{-5} \mathrm{Pc}^{\mathrm{r}}$ transformants per $\mu \mathrm{g}$ DNA. This represented a fivefold decrease in transformation efficiency, probably due to gonococcalspecific restriction of the plasmid DNA obtained from the $E$. coli strain. However, there were no significant differences (Student's $t$-test, $P<0.44$ ) in the DNA uptake of the two plasmid preparations. When pFA10 prepared from $N$. gonorrhoeae was used for uptake, a value of 1848 \pm 165 c.p.m. (mean $\pm \mathrm{SE}$ ) was obtained for hybridization to lysates of gonococci incubated with this plasmid, compared to $1840 \pm 152$ c.p.m. obtained when pFA10 from $E$. coli was the donor DNA. We concluded that, although restriction of incoming plasmid DNA (prepared from $E$. coli) probably resulted in the decreased transformation efficiency, there was no effect of gonococcal-specific DNA modification on uptake of plasmid DNA.

\section{DISCUSSION}

It was reported previously that two overlapping ${ }^{32} \mathrm{P}$-end-labelled restriction fragments consisting of gonococcal cryptic plasmid (pFA1) sequences were taken up in preference to fragments derived from the Pcr plasmid pFA3 (Graves et al., 1982b). Using a different method of detection from that of Graves et al. (1982b), namely hybridization to a homologous nick- 
translated probe, we have confirmed that this observation was due to preferential uptake and not due to selective processing of ends of incoming fragments.

Using a recombinant plasmid containing only the $600 \mathrm{bp} \mathrm{TaqI-MspI} \mathrm{overlap} \mathrm{fragment,} \mathrm{we}$ determined that this region of pFA10 was preferentially taken up, as predicted (Graves et al., $1982 \mathrm{~b}$ ). We also identified a second region on the cryptic plasmid which was selectively taken up. These two fragments originate from different cryptic plasmid isolates pFA1 and pJD1, but the two plasmids are identical in size and have very similar physical maps (Davies \& Normark, 1980; Foster \& Foster, 1976; Korch et al., 1985). The 600 bp fragment in pSTD6 was derived from pJD1, and thus the sequence of this fragment is known. Our sequence results for the $370 \mathrm{bp}$ $D d e I$ fragment from pFAl showed that it contains a direct repeat of a $10 \mathrm{bp}$ sequence found in the 600 bp TaqI-MspI fragment, as expected based on the results published for pJD1 (Korch et $a l .$, 1985). This $10 \mathrm{bp}$ sequence ( $5^{\prime}$ GATGCTCTGT $\left.3^{\prime}\right)$ is absent from the pFAl fragments that are not preferentially taken up by the competent gonococci. We also found a restriction fragment from the M13 genome which was selectively taken up. This fragment does not contain the pFAl $10^{*}$ mer.

None of the methods discussed here enables us to differentiate with absolute certainty between selective uptake of fragments and equal uptake of all fragments with subsequent degradation of some fragments. However, degradation of selected fragments is unlikely, since we have not seen significant lower molecular mass radioactivity on gels of cell lysates following uptake. Also, we cannot formally exclude the possibility that those fragments identified as being taken up were not actually processed forms of larger fragments from the restriction digest. Since the fragments used for uptake were radiolabelled by replacement synthesis, both ends of the molecule contain extensive ${ }^{32} \mathrm{P}$ label. It is therefore possible that the fragments could have been processed to a smaller size and still retain ${ }^{32} \mathrm{P}$ label. However, using a variety of different restriction digests, our results were internally consistent as to which regions were preferred for uptake. Taken together, the results are highly unlikely to be due to selective degradation or processing of incoming fragments.

The precise mechanism of selective uptake is unclear. Korch et al. (1983) suggested that the extensive methylation of gonococcal DNA might contribute to its specific recognition for DNA uptake. However, we found that gonococcal DNA modification is not required for efficient uptake. In Haemophilus, specificity for uptake is retained when cloned Haemophilus DNA fragments have been propagated in E. coli (Chung \& Goodgal, 1979; Sisco \& Smith, 1979). These results indicate that preferential uptake in $N$. gonorrhoeae, like that in Haemophilus, does not depend on homologous DNA modification.

In Haemophilus, homologous DNA uptake is facilitated by presence of a specific $11 \mathrm{bp}$ sequence (Danner et al., 1980, 1982). We wanted to determine if the cryptic plasmid $10 \mathrm{bp}$ sequence played an analogous role in DNA uptake in the gonococcus. The derivative of pBR322 containing the $10 \mathrm{bp}$ sequence was taken up to essentially the same extent as either pBR322 $\triangle B-S$ lacking this sequence or pBR322 $\triangle \mathrm{B}-\mathrm{S}$ containing an unrelated $10 \mathrm{bp}$ oligonucleotide. Moreover, an M13 (mp19) DNA fragment without significant homology to the 10 bp sequence was taken up efficiently, and M13 DNA fragments containing the core $8 \mathrm{bp}$ of the $10^{*}$ mer were not taken up as efficiently as other fragments lacking this sequence. These data indicate that the pFA1 $10^{*}$ mer is not sufficient to explain preferential DNA uptake by competent gonococci.

There are several possible reasons why the $10^{*}$ mer did not confer increased uptake. Its presence on the two cryptic plasmid fragments which were selectively taken up may be coincidental. This argument is strengthened by the fact that the M13 DNA fragment which is selectively taken up does not contain any sequences with significant homology to this $10 \mathrm{bp}$ sequence. Alternatively, we may have failed to identify auxiliary sequences which might be required for specific uptake. For instance, a putative gonococcal DNA receptor may interact with two non-contiguous sites on a DNA molecule, the $10^{*}$ mer possibly being only one of those sites. An example of this type of protein-DNA interaction is seen in type 1 restriction endonucleases. These enzymes recognize two sequences of 3-4 bp that are separated by six or eight bases of random DNA sequence (Yuan, 1981). More work is required before the basis for selective DNA uptake by gonococci is understood. 
This work was supported by Public Health Service grant AI15036 from the National Institute of Allergy and Infectious Diseases, and Genetics Curriculum Training Grant no. T32 GM07092-11 from the National Institutes of Health. We are grateful to Lynn Brooks for typing the manuscript, Gour Biswas for helpful advice, and Magdalene So for providing us with the plasmid pGUT. We thank Staffan Normark for communicating pJDI sequence data prior to publication, Gail Wertz for use of the scanning densitometer, and John Glass for his instruction on the densitometer. We also thank Clyde Hutchison and Bruce Wisely for synthesis of the oligonucleotides used in this study.

\section{REFERENCES}

Birnboim, H. C. \& Doly, J. (1979). A rapid alkaline extraction procedure for screening recombinant plasmid DNA. Nucleic Acids Research 7, 1513-1523.

Biswas, G. D., Sox, T., Blackman, E. \& Sparling, P. F. (1977). Factors affecting genetic transformation of Neisseria gonorrhoeae. Journal of Bacteriology 129, 983-992.

Biswas, G. D., Burnstein, K. L. \& Sparling, P. F. $(1986 a)$. Linearization of donor DNA during plasmid transformation in Neisseria gonorrhoeae. Journal of Bacteriology 168, 756-761.

Biswas, G. D., Graves, J., Schwalbe, R. \& Sparling, P. F. $(1986 b)$. Construction of isogenic gonococcal strains varying in the presence of a $4 \cdot 2$-kilobase cryptic plasmid. Journal of Bacteriology 167, 685694.

Chung, B. C. \& Goodgal, S. H. (1979). The specific uptake of cloned Haemophilus DNA. Biochemical and Biophysical Research Communications 88, 203214.

Dagert, M. \& Ehrich, S. D. (1979). Prolonged incubation in calcium chloride improves the competence of Escherichia coli cells. Gene 6, 23-28.

Danner, D. B., Deich, R. A., Sisco, K. L. \& Smith, H. O. (1980). An 11-base pair sequence determines the specificity of DNA uptake in Haemophilus transformation. Gene 11, 311-318.

DANNER, D. B., SMITH, H. O. \& NARANG, S. A. (1982). Construction of DNA recognition sites active in Haemophilus transformation. Proceedings of the National Academy of Sciences of the United States of America 79, 2293-2297.

DAvies, J. K. \& NoRmarK, S. (1980). A relationship between plasmid structure, structural lability, and sensitivity to site-specific endonucleases in Neisseria gonorrhoeae. Molecular and General Genetics 177, 251-260.

DEICH, R. A. \& SMITH, H. O. (1980). Mechanism of homospecific DNA uptake in Haemophilus influenzae transformation. Molecular and General Genetics 177, 369-374.

Dougherty, T., Asmus, A. \& Tomasz, A. (1979). Specificity of DNA uptake in genetic transformation of gonococci. Biochemical and Biophysical Research Communications 86, 97-104.

FOSTER, R. S. \& FoSTER, G. C. (1976). Electrophoretic comparison of endonuclease-digested plasmids from Neisseria gonorrhoeae. Journal of Bacteriology 126 , 1297-1304.

Goodgal, S. H. (1982). DNA uptake in Haemophilus transformation. Annual Review of Genetics 16, 169192.

Graves, J. F., Biswas, G. D., Blackman, E. Y. \& SPARLING, P. F. (1982a). Transformation of penicillinase-producing plasmids in Neisseria gonorrhoeae.
In Genetic Exchange, pp. 61-71. Edited by U. N. Streips, S. H. Goodgal, W. R. Guild \& G. A. Wilson. New York: Marcel Dekker.

Graves, J. F., Biswas, G. D. \& Sparling, P. F. $(1982 b)$. Sequence-specific DNA uptake in transformation of Neisseria gonorrhoeae. Journal of Bacteriology 152, 1071-1077.

HANAHAN, D. (1983). Studies on transformation of Escherichia coli with plasmids. Journal of Molecular Biology 166, 557-580.

Hutchison, C. A., III, NoRdeEn, S. K., Vogt, K. \& EDGELL, M. H. (1986). A complete library of point substitution mutations in the glucocorticoid response element of mouse mammary tumor virus. Proceedings of the National Academy of Sciences of the United States of America 83, 710-714.

Korch, C., Hagblom, P. \& Normark, S. (1983). Sequence-specific DNA modification in Neisseria gonorrhoeae. Journal of Bacteriology 155, 1324 1332.

Korch, C., Hagblom, P., Ohman, H., Goransson, M. \& NoRmaRK, S. (1985). Cryptic plasmid of Neisseria gonorrhoeae: complete nucleotide sequence and genetic organization. Journal of Bacteriology 163, 430-438.

LeBlanc, D. J. \& Hassell, F. P. (1976). Transformation of Streptococcus sanguis Challis by plasmid deoxyribonucleic acid from Streptococcus faecalis. Journal of Bacteriology 128, 347-355.

Maniatis, T., Fritsch, E. F. \& SAmbroOK, J. (1982). Molecular Cloning. A Laboratory Manual. Cold Spring Harbor, NY: Cold Spring Harbor Laboratory.

O'Farrell, P. H., Kutter, E. \& Nakanishi, M. (1980). A restriction map of the bacteriophage T4 genome. Molecular and General Genetics 179, 421435.

Radloff, R., Bauer, W. \& Vinograd, J. (1967). A dye-buoyant-density method for the detection and isolation of closed circular duplex DNA: the closed circular DNA in HeLa cells. Proceedings of the National Academy of Sciences of the United States of America 57, 1514-1521.

SANGer, F., Nicklen, S. \& Coulson, A. (1977). DNA sequencing with chain-terminating inhibitors. Proceedings of the National Academy of Sciences of the United States of America 74, 5463-5467.

Sarubi, F. A., JR, Blackman, E. \& Sparling, P. F. (1974). Genetic mapping of linked antibiotic resistance loci in Neisseria gonorrhoeae. Journal of Bacteriology 120, 1284-1292.

Scocca, J. J., Poland, R. L. \& Zoon, K. C. (1974). Specificity in deoxyribonucleic acid uptake by transformable Haemophilus influenzae. Journal of Bacteriology 118, 369-373. 
Sisco, K. L. \& SMITH, H. O. (1979). Sequence-specific DNA uptake in Haemophilus transformation. Proceedings of the National Academy of Sciences of the United States of America 76, 972-976.

Smith, G. E. \& Summers, M. D. (1980). The bidirectional transfer of DNA and RNA to nitrocellulose- or diazobenzyloxymethyl-paper. Analytical Biochemistry 109, 123-129.

SMITh, H. O., DanneR, D. B. \& Deich, R. A. (1981). Genetic transformation. Annual Review of Biochemistry 50, 41-68.

Sox, T. E., Mohammed, W. \& Sparling, P. F. (1979). Transformation-derived plasmids in Neisseria gonorrhoeae with altered structure and function. Journal of Bacteriology 138, 510-518.
SparlinG, P. F. (1966). Genetic transformation of Neisseria gonorrhoeae to streptomycin resistance. Journal of Bacteriology 92, 1364-1371.

Stein, D. C., Silver, L. E., Clark, V. L. \& Young, F. E. (1983). Construction and characterization of a new shuttle vector, pLES2, capable of functioning in Escherichia coli and Neisseria gonorrhoeae. Gene 25 , 241-247.

Vieira, J. \& MEssing, J. (1982). The pUC plasmids, an M13mp7-derived system for insertion mutagenesis and sequencing with synthetic universal primers. Gene 19, 259-268.

YUAN, R. (1981). Structure and mechanism of multifunctional restriction endonucleases. Annual Review of Biochemistry 50, 285-315. 